\title{
Nigeria's Star Game Reserve
}

\author{
Chris Geerling
}

One of the few conservation success stories in West Africa is Yankari Game Reserve in Nigeria, where, thanks to effective management, animal populations have increased to a level at which environmental factors (not human ones) have started to control numbers. Yankari offers the rare spectacle of an effective and efficiently managed reserve with an abundance of animals, which attracts increasing interest from Nigerians.

Originally a Local Authority Forest Reserve, Yankari became a Game Reserve in 1955. Effective protection started in the early sixties, ${ }^{4}$ since when the reserve has been managed by $\mathrm{Mr}$ Jibirin Jia assisted by staff trained at Mweka, the college in Tanzania for training game guards and wardens. Management consists of strict protection of the animals, non-intervention in the vegetation of the valleys, and control of fires in the upland savanna, and is in every respect as for a national park. Up to 10,000 paying visitors, more than half of them Nigerian, and numerous school parties come every year. Accommodation is at Wikki in the centre of the reserve, chosen because of the big warm spring which is used as a swimming pool. Visitors are taken on tours in open lorries, accompanied by a guide, so that disturbance is minimal and animals have become tame, especially buffalo, waterbuck and warthog. Wikki Camp shows the disadvantages of having tourist facilities inside a park or reserve, for the camp continues to grow at an almost exponential rate because of the need for additional supporting facilities for any new staff. However the camp is fortunately on top of the cliff overlooking the Wikki Spring, and not in the valley, which is the herbivores' main habitat in the dry season.

The reserve covers about $2240 \mathrm{sq} \mathrm{km}$ of rolling hill country in Bauchi State (formerly part of North-Eastern State) and is traversed by the deeply enclosed valley of the Gaji River, a permanent stream fed by a number of warm springs. ${ }^{5}$ The vegetation of the hill country is a rather dense Combretaceous savanna woodland, with a tall grass cover dominated by annuals. The Gaji valley, a floodplain between 0.5 and $1.0 \mathrm{~km}$ wide, consists of a mosaic of vegetation types, ranging from tall swamp forest to open grassland. ${ }^{2}$ A noteworthy feature are the monospecific woodlands on the valley slopes, formed by Pteleopsis habeensis (Combretaceae), a species which, outside the Yankari region, is known only from Ghana and Mali.

The reserve's fauna is typical of West African savanna; ${ }^{1}$ warthog

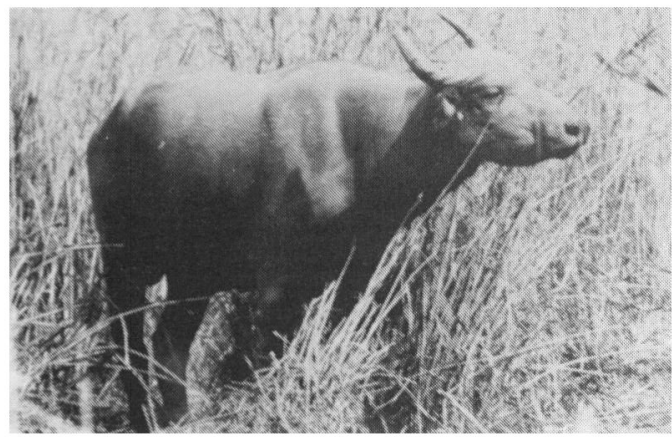


Phaecochoerus aethiopicus, buffalo Syncerus caffer, hartebeest Alcelaphus buselaphus, waterbuck Kobus defassa, and baboon Papio anubis are numerous; elephant Loxodonta africana, roan antelope Hippotragus equinus, bushbuck Tragelaphus scriptus, and red-flanked duiker Cephalophus rufilatus are common; green monkey Cercopithecus aethiops, hippopotamus Hippopotamus amphibius, oribi Ourebia oribi, grey duiker Sylvicapra grimmia and patas monkey Erythrocebus patas occur in small numbers. Among carnivores, lion Panthera leo are common; leopard Panthera pardus, serval Felis serval, caracal Felis caracal, spotted hyaena Crocuta crocuta, hunting dog Lycaon pictus, and jackals Canis spp. all occur, but numbers are difficult to estimate. Nile crocodile Crocodylus niloticus are common in the Gaji; slender-snouted crocodile Crocodylus cataphractus occur, but are less numerous. The permanent water in the valley supports a large number of large herbivores and carnivores, and also plant and animal species of more humid climatic zones, such as oil palm Elaeis guineensis (probably an ancient introduction), crested flycatcher Trochocerus nitens, and brush-tailed porcupine Atherurus sp., making the valley something of an ecologically humid island in dry savanna bush.

Some of the large herbivore populations, especially buffalo, waterbuck and hartebeest, have increased spectacularly in the last decade, showing that hunting has been the limiting factor in the past; now environmental factors, in this case availability of food in the critical season, have become limiting. The vegetation of the upland savanna is only used during the rainy season, before the grass becomes too fibrous and dry; in the dry season the animals concentrate in the Gaji valley, and the vegetation is heavily used, but there are no signs of degradation, such as erosion or increase of unpalatable plant species. $^{3}$ In the near future lack of food, rather than a collapse of the whole system, is expected to be the major regulating measure. Elephants, a species with potential for trouble, but still well below carrying capacity, are increasing and may in the future cause a profound vegetation change.

Carnivores have increased along with the herbivores. Lions, rarely seen in 1970 and 1971, are now commonly observed, crocodiles are more numerous than they were seven years ago, and kills of the large carnivores are also more commonly found. However, the larger herbivore populations are not yet in equilibrium with their environment, and the carnivores appear to be following rather than regulating herbivore numbers.

\section{References}

1 FAO, 1975. The ecology and management of Yankari Game Reserve, Technical Report. FO: DP/NIR/72/002, FAO, Rome.

2 GEERLING, C. 1973. The vegetation of Yankari Game Reserve: its utilization and condition. Bulletin no. 3, Department of Forestry, University of Ibadan, Nigeria, 49 pp.

3 GEERLING, C. in prep. Vegetation and herbivores in Yankari.

4 JIBIRIN JIA, M.O.N. The Yankari Game Reserve 1955-1970. IUCN Publications New Series 22: 27-30.

5 THOMAS, M.E.A., and S.K. SIKES 1971. Warm springs and multiple wells at Yankari. The Nigerian Field 36: $180 \mathrm{pp}$.

Chris Geerling, Nature Conservation Department, Agricultural University, Wageningen, Netherlands, formerly FAO Forestry Officer (Range Ecology) at the Ecole pour la Formation de Spécialistes de la Faune, Garoua, Cameroun. 